\title{
Comparative Study of Glyphosate and AMPA Determination in Environmental Samples by Two Green Methods
}

\author{
Bruno Molero da Silva1, Fernanda Benetti², Maria Olímpia Oliveira Rezende ${ }^{3}$ \\ ${ }^{1}$ State University of Campinas, Campinas, São Paulo, Brazil \\ ${ }^{2}$ Chemistry Institute of São Carlos, University of São Paulo, São Paulo, Brazil \\ ${ }^{3}$ Institute of Chemistry of São Carlos, University of São Paulo, São Paulo, Brazil

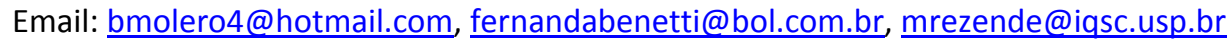

Received 12 May 2015; accepted 28 May 2015; published 2 June 2015

Copyright (C) 2015 by authors and OALib.

This work is licensed under the Creative Commons Attribution International License (CC BY). http://creativecommons.org/licenses/by/4.0/

(c) (i) Open Access

\begin{abstract}
Glyphosate, N-phosphonomethyl-glycine (GLY), is a systemic post-emergence herbicide that controls weeds with great efficiency whose low cost is reflected in its wide application. In the environment, the presence of aminomethylphosphonic acid (AMPA), its main degradation product, is indicative of the application of GLY to the land. The aim of this study was to develop two analytical methods for the determination of GLY by HPLC-UV and GLY and AMPA by GC-MS, in water, soil and sediment samples. The proposed HPLC-UV method proved to be an efficient way of determining GLY in environmental samples of water, soil and sediment, eliminating the step of extraction and clean-up. On the other hand, the GC-MS method can be used to determine both GLY and AMPA simultaneously. The limits of detection (LOD) and quantitation (LOQ) for GLY by the HPLC method were 9.93 and $30.1 \mu \mathrm{g} \cdot \mathrm{L}^{-1}$ for water samples, and 0.040 and $0.120 \mathrm{mg} \cdot \mathrm{kg}^{-1}$ for soil and sediment samples, respectively. By the GC-MS method, the LOD and LOQ for GLY were 0.67 and $2.02 \mu \mathrm{g} \cdot \mathrm{L}^{-1}$ for water samples, and 0.0027 and $0.0081 \mathrm{mg} \cdot \mathrm{kg}^{-1}$ for soil and sediment samples, respectively. For AMPA, these limits were 0.15 and $0.45 \mu \mathrm{g} \cdot \mathrm{L}^{-1}$ for water samples and 0.0006 and $0.0018 \mathrm{mg} \cdot \mathrm{kg}^{-1}$ for soil and sediment samples, respectively. The recoveries ranged from $70 \%$ to $120 \%$ for water, soil and sediment samples.
\end{abstract}

\section{Keywords}

Glyphosate, AMPA, Environmental Samples, HPLC-UV, GC-MS

Subject Areas: Environmental Chemistry

How to cite this paper: da Silva, B.M., Benetti, F. and Rezende, M.O.O. (2015) Comparative Study of Glyphosate and AMPA Determination in Environmental Samples by Two Green Methods. Open Access Library Journal, 2: e1553.

http://dx.doi.org/10.4236/oalib.1101553 


\section{Introduction}

Glyphosate, N-(phosphonomethyl)-glycine (GLY) is a broad-spectrum systemic post-emergence herbicide which is very efficient in removing invasive plants and shows a low toxicity to those who apply it to the land. GLY is currently the most widely used herbicide in the world, representing about $60 \%$ of all marketed non-selective herbicides [1]. It is relatively inexpensive and highly effective in agriculture, hence its widespread use. When applied to the soil, part of the herbicide may be washed off or leached, thus reaching aquatic environments. Therefore, the possibility of environmental contamination with this molecule should be monitored carefully. In addition, the commercial formulation contains a surfactant that irritates the skin [2]. Aminomethylphosphonic acid (AMPA) is its main microbial degradation product.

AMPA has an $\mathrm{LD}_{50}$ of $8300 \mathrm{mg} \cdot \mathrm{kg}^{-1}$ for rats, while its toxicity is low; it is much more persistent in nature than GLY. The presence of AMPA in the environment indicates the application of GLY. Studies estimate that the half-life of glyphosate in water may be less than 3 days, while that of AMPA varies between 119 and 958 days [3]. Therefore, it is necessary to develop methods of extracting and determining AMPA, for correct quantitation. AMPA is the only metabolite of glyphosate found in significant amounts in biological systems, being moderately absorbed by the digestive tract, and its excretion occurs almost entirely in the urine [4].

The determination of GLY and AMPA represents an analytical challenge, due to their high solubility in water, low solubility in organic solvents and low volatility [5].

Most GLY extraction procedures are based on acid-base reactions, since the compound is initially bound to solid ionic species via the phosphate group, and then starts to interact with ions in the soil solution. Thus, solutions of strong bases, salts of strong bases, weak bases or weak acids are generally used for extraction [6].

A variety of analytical methods have been applied to the determination of GLY, gas chromatography and liquid chromatography being the commonest [7] [8].

The chromatographic determination of glyphosate needs to be adapted in order to permit its detection. Adaptations include mainly derivatization reactions or alteration of some physical properties that may be related to the amount of glyphosate in the sample [8]. In HPLC-FD, there is the need to promote fluorescence molecule, and the derivatizing reagent mostly used is o-phthalaldehyde (OPA), FMOC-Cl and p-toluenesulphonyl chloride. This method is the most cited in literature. For LC-MS, the most used derivatizing reagent is FMOC-Cl [2]. In gas chromatography, derivatization is required to decrease its polarity and increase volatility [5]. Generally, the process involves the addition of an excess of trifluoroacetic anhydride (TFAA) and trifluoroethanol (TFE) [9].

The method proposed here affords effective detection and measurement of glyphosate and its major metabolite, AMPA, in environmental samples of water, soil and sediment, via the techniques of HPLC-UV and GC-MS. Using HPLC-UV, glyphosate can be determined in a simple and quick step without clean-up. For multiresidue determination, GC-MS is suggested. The methods presented herein have been applied to environmental samples.

\section{Experimental}

\subsection{Equipment}

The quantitation of GLY was performed with a high performance liquid chromatography system (HPLCShimadzu LC-10AVP), UV-Vis Detector (Shimadzu SPD-10VP). GLY and AMPA were also determined with gas chromatograph coupled to a mass spectrometer (Shimadzu QP 210 Plus), with automatic injector (Shimadzu).

\subsection{Reagents and Solutions}

Stock solutions of glyphosate and AMPA $\left(500 \mu \mathrm{g} \cdot \mathrm{L}^{-1}\right)$ were prepared in aqueous $0.1 \mathrm{~mol} \cdot \mathrm{L}^{-1} \mathrm{KH}_{2} \mathrm{PO}_{4}$. The herbicide was acquired from Sigma Aldrich Laborchemikalien GmbH, Seelze-Germany. The stock herbicide solutions were diluted with ultra-purified water (Milli-Q) to obtain working solutions. Phosphoric acid (Tedia, $85 \%)$ was used.

\subsection{Sampling and Sample Preparation}

The study was conducted in the basin of the Jacaré-Guaçu river, an important tributary of the Tietê river, located in the central-eastern region of São Paulo state, with the following coordinates: $21^{\circ} 57^{\prime} 30^{\prime \prime}$ to $22^{\circ} 22^{\prime} 30^{\prime \prime} \mathrm{S}$ by $47^{\circ} 42^{\prime} 30^{\prime \prime}$ to $48^{\circ} 05^{\prime} 30^{\prime \prime} \mathrm{W}$ [10]. Figure 1 shows the location of the Jacaré-Guaçu river basin [11]. 


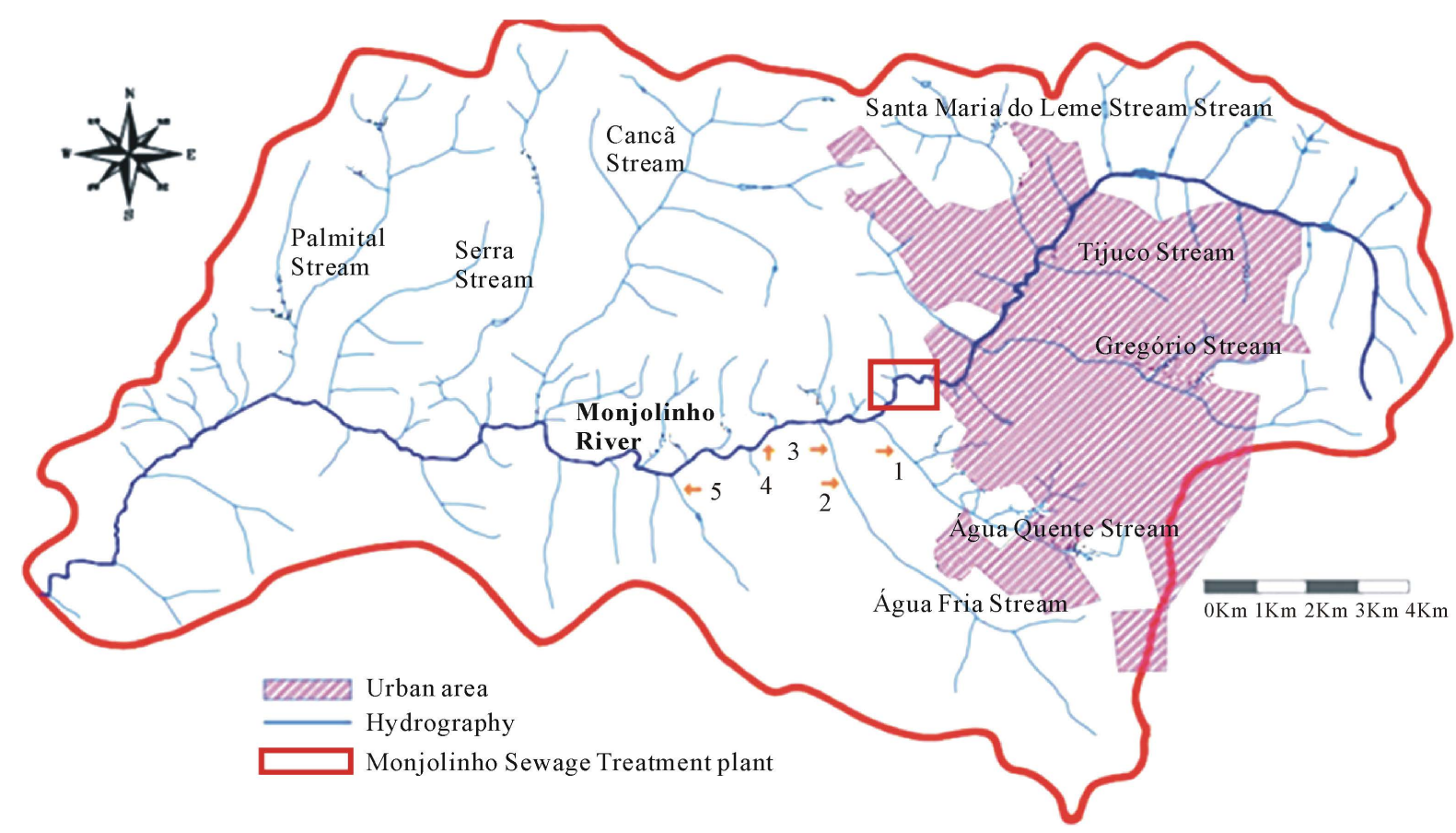

Figure 1. Jacaré-Guaçu river basin and São Carlos city (adapted from [11]).

Water samples were collected in the Monjolinho river and its tributary streams, in São Carlos (SP). It is worth noting the presence of interfering substances in the samples originating in the contamination due to the disposal of domestic sewage. Currently, most of the urban sewage in this city is treated.

Soil and sediment samples were collected with the aid of a spade and transported in coolers with ice to the laboratory, where they were kept in a freezer at $-10^{\circ} \mathrm{C}$ [12].

Waters, soils and sediments were characterized chemically for the following variables: $\mathrm{pH}$ in $\mathrm{CaCl}_{2}$, total carbon via Shimadzu TOC-V COH, cation exchange capacity (CEC), total solids, total dissolved solids, organic matter (OM), Kjeldahl nitrogen, phosphorus, biological oxygen demand (BOD), chemical oxygen demand (COD) and silt and clay fractions, via densitometer [13] [14]. In addition, humic substances were analyzed quantitatively: humic and fulvic acids were determined by conventional methodology suggested by the International Humic Substances Society [15].

\subsection{Sample Preparation for Glyphosate Determination by HPLC-UV}

Water samples were acidified to $\mathrm{pH} 2.0$ with phosphoric acid, filtered through a syringe membrane filter of pore $0.45 \mu \mathrm{m}$ and injected into the HPLC-UV without any extraction or clean-up steps.

Soil samples were placed in a drying oven for 24 hours at a temperature of $40^{\circ} \mathrm{C}$. Aliquots of $5 \mathrm{~g}$ of dried soil were then taken for the determinations. The same procedure was followed for sediment samples. Each aliquot was subjected to solid-liquid extraction with $20 \mathrm{~mL}$ of $0.1 \mathrm{~mol} \cdot \mathrm{L}^{-1} \mathrm{KH}_{2} \mathrm{PO}_{4}$ for 45 minutes in a rotary shaker at $200 \mathrm{rpm}$. The solid was allowed to settle and the supernatant decanted. An aliquot of the supernatant was filtered and determined by HPLC-UV.

The recovery study was conducted at 3 concentration levels in water samples: low (50 $\left.\mu g \cdot \mathrm{L}^{-1}\right)$, medium (300 $\left.\mu \mathrm{g} \cdot \mathrm{L}^{-1}\right)$ and high $\left(500 \mu \mathrm{g} \cdot \mathrm{L}^{-1}\right)$.

The same procedure was followed using the standard solution at concentrations of $2 \mathrm{mg} \cdot \mathrm{L}^{-1} \mathrm{and} 3 \mathrm{mg} \cdot \mathrm{L}^{-1}$. Then, a previously filtered aliquot was injected into the HPLC-UV, without clean-up. Various soils were analyzed to obtain the percentage recovery of GLY and thus to provide a method capable of assessing soils of different regions. To choose the optimum absorption wavelength of the analyte, the sprectrum of a standard aqueous glyphosate solution of $500 \mu \mathrm{g} \cdot \mathrm{L}^{-1}$ was collected in a UV-Vis spectrophotometer.

Owing to its high polarity and for not being a volatile molecule, GLY was determined by HPLC with an anion exchange column, Partisil 10 SAX, $25 \mathrm{~cm}$ long by $4.6 \mathrm{~mm}$ internal diameter. The column temperature was 
maintained at $25^{\circ} \mathrm{C}$ and the absorption detected at $195 \mathrm{~nm}$. The injection volume was constant at $20 \mu \mathrm{L}$.

The mobile phase was a phosphate buffer solution prepared by dissolving $0.68 \mathrm{~g}$ of $\mathrm{KH}_{2} \mathrm{PO}_{4}$ in ultra-pure water and adding $\mathrm{H}_{3} \mathrm{PO}_{4}(85 \%)$ until $\mathrm{pH}=2$, then completing the volume to a liter with ultra-pure water. The elution was isocratic, with a flow rate of $2.3 \mathrm{~mL} \cdot \mathrm{min}^{-1}$.

\subsection{Preparation of Samples for Analysis of Glyphosate and AMPA by GC-MS}

The extraction and clean-up procedures for the water and the soil or sediment samples were performed as described by Souza et al. [6] and Börjesson and Torstensson [9]. The recovery tests for GLY and AMPA in water were performed at three concentrations levels, low $\left(30 \mu \mathrm{g} \cdot \mathrm{L}^{-1}\right)$, medium $\left(90 \mu \mathrm{g} \cdot \mathrm{L}^{-1}\right)$ and high $\left(200 \mu \mathrm{g} \cdot \mathrm{L}^{-1}\right)$. For soil and sediment, the three levels were: low $\left(6 \mathrm{mg} \cdot \mathrm{kg}^{-1}\right)$, medium $\left(12 \mathrm{mg} \cdot \mathrm{kg}^{-1}\right)$ and high $\left(60 \mathrm{mg} \cdot \mathrm{kg}^{-1}\right)$.

The chromatographic determinations were carried out in a GC-MS system, with oven temperature starting at $80^{\circ} \mathrm{C}$ and after 2 minutes, at a rate of $28.8^{\circ} \mathrm{C} \mathrm{min}{ }^{-1}$, the temperature was increased to $270^{\circ} \mathrm{C}$ (the total running time was 8.6 minutes), injector temperature at $280^{\circ} \mathrm{C}$, temperature of the interface at $260^{\circ} \mathrm{C}$, ion source temperature at $200^{\circ} \mathrm{C}$, total flow of carrier gas helium at $15.1 \mathrm{~mL} \cdot \mathrm{min}^{-1}$, column flow at $2.02 \mathrm{~mL} \cdot \mathrm{min}^{-1}$, linear velocity at $57.3 \mathrm{~cm} \cdot \mathrm{s}^{-1}$, injection mode splitless and pressure of $22.4 \mathrm{kPa}$. The monitored ions for AMPA had $\mathrm{m} / \mathrm{z} 246$ and 302 and those for glyphosate were $\mathrm{m} / \mathrm{z} 246,260$ and 411 . Wastes were discharged safety [16].

The proposed methods were assessed with respect to selectivity, sensitivity, linearity, limit of detection (LOD), limit of quantitation (LOQ), accuracy, precision and robustness.

Studies were designed, performed, monitored, recorded, archived and reported in keeping with the principles of good laboratory practice [17].

All determinations were performed in triplicate, and the error was determined for a confidence interval of 95\%, according to Student's Test [18].

\section{Results and Discussion}

\subsection{Physicochemical Characterization of the Samples}

To better understand the variation in the recovery of GLY and AMPA, physical and chemical characteristics of water, soil and sediment samples were determined. For the physicochemical characterization of water samples, the tests listed in Table 1 were performed.

It is important to emphasize that the sampling sites in the Monjolinho stream have a high phosphorus concentration, greater than the established limit in Brazilian law [19] for Class 2 waters $\left(0.05 \mathrm{mg} \cdot \mathrm{L}^{-1}\right)$, which could indicate the presence of fertilizers such as NPK or the discharge of domestic sewage into the stream. It should also be mentioned that this is an agricultural area. Between the rivers Feijão and Jacaré-Guaçu, land is used mainly for pasture, coffee, sugar-cane, corn and citrus, with a predominance of small and medium farmers.

The closest of the five sampling sites to Monjolinho Sewage Treatment Station (Site 1) showed a very high total Kjeldahl nitrogen content (the legal limit is $2.18 \mathrm{mg} \cdot \mathrm{L}^{-1}$ for Class 2 waters) [19]. Another variable that indicates the presence of domestic sewage discharge is the high value of BOD at this site (maximum $5 \mathrm{mg} \cdot \mathrm{L}^{-1}$ for Class 2 waters, by law [19]).

The results for soil samples are presented in Table 2.

Table 1. Results of pH, COD, BOD, total solids, total dissolved solids, Kjeldahl nitrogen and phosphorus in water.

\begin{tabular}{cccccccc}
$\begin{array}{c}\text { Sampling } \\
\text { Site }\end{array}$ & $\mathrm{pH}$ & $\begin{array}{c}\mathrm{COD}^{\mathrm{a}} \\
\left(\mathrm{mg} \mathrm{O}_{2} \mathrm{~L}^{-1}\right)\end{array}$ & $\begin{array}{c}\mathrm{BOD}^{\mathrm{b}} \\
\left(\mathrm{mg} \mathrm{O}_{2} \mathrm{~L}^{-1}\right)\end{array}$ & $\begin{array}{c}\text { Total Solids } \\
\left(\mathrm{mg} \cdot \mathrm{L}^{-1}\right)\end{array}$ & $\begin{array}{c}\text { Total Dissolved } \\
\text { Solids }\left(\mathrm{mg} \cdot \mathrm{L}^{-1}\right)\end{array}$ & $\begin{array}{c}\text { Kjeldahl Nitrogen } \\
\left(\mathrm{mg} \cdot \mathrm{L}^{-1}\right)\end{array}$ & $\begin{array}{c}\text { Phosphorus } \\
\left(\mathrm{mg} \cdot \mathrm{L}^{-1}\right)\end{array}$ \\
1 & $7.15 \pm 0.16$ & 128 & 36 & $254.19 \pm 6.23$ & $123.81 \pm 6.84$ & $13.0 \pm 0.40$ \\
2 & $6.46 \pm 0.10$ & 32 & 12 & $23.74 \pm 2.37$ & $23.57 \pm 2.02$ & $1.00 \pm 0.09$ & $3.00 \pm 0.09 \pm 0.01$ \\
3 & $6.46 \pm 0.12$ & 12 & 2 & $57.52 \pm 2.98$ & $21.67 \pm 1.86$ & $0.06 \pm 0.01$ \\
4 & $7.43 \pm 0.77$ & 23 & 7 & $199.0 \pm 3.0$ & $135.11 \pm 4.26$ & $7.00 \pm 0.17$ & $0.15 \pm 0.01$ \\
5 & $7.41 \pm 0.47$ & 6 & 1 & $87.46 \pm 11.05$ & $21.75 \pm 1.91$ & $2.00 \pm 0.19$ \\
\hline
\end{tabular}

${ }^{\mathrm{a}, \mathrm{b}}$ Determinations performed at Laboratory of Sanitation, EESC-USP. 
Site 4 showed the highest percentage of organic matter. Brazilian soils are acidic in general. Thus, the values found in these samples coincide with the values found in the great majority of Brazilian soils [20].

The highest values for CEC of the soil samples were observed at the sampling Site 5 and the lowest value at Site 4. The CEC is defined as the quantity of cations that the soil can retain on its negative charges, which in turn are mostly present on the phenolic and carboxilic groups of humic acids, which have easily ionizable hydrogens.

The dissociation of hydrogen leaves negative sites in humic substances, which can attract cations $\left(\mathrm{Ca}^{2+}, \mathrm{Mg}^{2+}\right.$ and $\mathrm{K}^{+}$). These acid groups are primarily responsible for the interactions that occur between pesticides and humic acids.

The highest percentage of humic acids was found at Site 1 and the lowest at Site 3, as can be seen in Table 2 . The concentration of total carbon ranged from 38.17 to $2.87 \mathrm{~g} \cdot \mathrm{kg}^{-1}$. Soil samples from Site 1 had the highest concentration of total organic carbon, while those from Site 3 had the lowest.

In assessing the chemical characteristics of the soil, the clay and silt contents must be considered, owing to their influence on the recovery of the herbicide (Table 2). The results of sediment samples characterization are presented in Table 3.

The organic matter content of sediment samples was lower than that for the majority of the soil samples around. Araújo et al. found higher levels of organic matter (about three times more) in five different Brazilian soils [21]. The highest value was at Site 5 (5.86\%) and lowest at Site $2(0.48 \%)$. As can be seen in Table 3, the sediment at all five sites is very sandy (more than $80 \%$ sand). It can be observed that the sediments contained widely varying quantities of Kjeldahl nitrogen and phosphorus, the greatest amounts being found at Site 4 .

The sediment at Site 5 had the greatest CEC, which could reflect its organic matter content. As mentioned above, the sediment samples were largely sand; this fraction prevailed at all five sites, with more than $80 \%$ at Site 5 and more than $90 \%$ at the others. The percentage of clay and silt was less than $5 \%$, except at Sites 4 and 5 . As there was a high sand content and low contents of clay, silt and organic matter, it is expected that the compounds of interest (glyphosate and AMPA) were dissolved in water and adsorbed on suspended matter and are not present in the sediment, since it was poor in binding sites.

Table 2. Results of $\mathrm{pH}$, organic matter, $\mathrm{CEC}_{\mathrm{ef}}$, total humic matter, total carbon, silt and clay in soil samples.

\begin{tabular}{|c|c|c|c|c|c|c|c|}
\hline $\begin{array}{l}\text { Sampling } \\
\text { Site }\end{array}$ & $\mathrm{pH}$ & $\begin{array}{c}\text { Organic } \\
\text { Matter (\%) }\end{array}$ & $\begin{array}{c}\text { CEC } \\
\left(\mathrm{cmol}_{\mathrm{c}} \cdot \mathrm{kg}^{-1}\right)\end{array}$ & $\begin{array}{l}\text { Total Humic } \\
\text { Matter (\%) }\end{array}$ & $\begin{array}{l}\text { Total Carbon } \\
\left(\mathrm{g} \cdot \mathrm{kg}^{-1}\right)\end{array}$ & Silt $^{\mathrm{a}}(\%)$ & Clay $^{\mathrm{b}}(\%)$ \\
\hline 1 & $4.97 \pm 0.02$ & $2.65 \pm 0.03$ & $5.06 \pm 0.36$ & $18.15 \pm 0.90$ & $38.17 \pm 0.68$ & 2.5 & 7.6 \\
\hline 2 & $4.12 \pm 0.01$ & $2.80 \pm 0.04$ & $2.42 \pm 0.45$ & $6.57 \pm 1.00$ & $8.25 \pm 0.90$ & 11.7 & 10.7 \\
\hline 3 & $5.73 \pm 0.01$ & $2.77 \pm 0.03$ & $1.98 \pm 0.58$ & $5.94 \pm 0.90$ & $2.87 \pm 0.75$ & 2.1 & 1.4 \\
\hline 4 & $5.08 \pm 0.01$ & $5.31 \pm 0.03$ & $1.81 \pm 0.48$ & $20.74 \pm 0.50$ & $31.64 \pm 0.68$ & 9.2 & 8.4 \\
\hline 5 & $4.75 \pm 0.01$ & $3.09 \pm 0.02$ & $5.28 \pm 0.50$ & $14.49 \pm 0.70$ & $35.26 \pm 0.90$ & 6.5 & 9.0 \\
\hline
\end{tabular}

${ }^{\mathrm{a}, \mathrm{b}}$ Determinations performed at Laboratory of Geotechnics, EESC-USP.

Table 3. Results of pH, organic matter, Kjeldahl nitrogen, $\mathrm{CEC}_{\mathrm{ef}}$, phosphorus, sand and fine particles in sediment samples.

\begin{tabular}{|c|c|c|c|c|c|c|c|}
\hline $\begin{array}{l}\text { Sampling } \\
\text { Site }\end{array}$ & $\mathrm{pH}$ & $\begin{array}{l}\text { Organic } \\
\text { matter }(\%)\end{array}$ & $\begin{array}{c}\text { Kjeldahl Nitrogen } \\
\left(\mathrm{mg} \cdot \mathrm{kg}^{-1}\right)\end{array}$ & $\begin{array}{c}\mathrm{CEC} \\
\left(\mathrm{cmol}_{\mathrm{c}} \cdot \mathrm{kg}^{-1}\right)\end{array}$ & $\begin{array}{l}\text { Total Phosphorus } \\
\left(\mathrm{mg} \cdot \mathrm{kg}^{-1}\right)\end{array}$ & Sand $^{\mathrm{a}}(\%)$ & $\begin{array}{c}(\text { Silt }+ \text { Clay })^{b} \\
(\%)\end{array}$ \\
\hline 1 & $6.26 \pm 0.08$ & $1.24 \pm 0.04$ & $450.7 \pm 1.9$ & $4.77 \pm 0.35$ & $75.1 \pm 7.5$ & 92.7 & 4.2 \\
\hline 2 & $6.66 \pm 0.07$ & $0.48 \pm 0.02$ & $74.3 \pm 1.0$ & $3.30 \pm 0.22$ & $616.9 \pm 35.8$ & 95.7 & 3.2 \\
\hline 3 & $5.25 \pm 0.09$ & $2.68 \pm 0.09$ & $73.3 \pm 2.6$ & $0.87 \pm 0.05$ & $604.7 \pm 35.8$ & 96.2 & 3.0 \\
\hline 4 & $6.06 \pm 0.05$ & $1.78 \pm 0.08$ & $1276.0 \pm 4.5$ & $5.34 \pm 0.31$ & $1427.7 \pm 30.0$ & 93.8 & 5.8 \\
\hline 5 & $5.78 \pm 0.09$ & $5.86 \pm 0.13$ & $900.7 \pm 3.5$ & $6.65 \pm 0.26$ & $1253.8 \pm 35.8$ & 83.7 & 10.4 \\
\hline
\end{tabular}

${ }^{\mathrm{a}, \mathrm{b}}$ Determinations performed at Laboratory of Geotechnics, EESC-USP. 


\subsection{Determination of Glyphosate by HPLC-UV in Environmental Samples}

\subsubsection{Water Samples}

To confirm the reproducibility and repeatability of the proposed method, analytical validation tests were carried out. The selectivity of the method was assessed by adding the reference substance to the matrix, river water in this case. No interference was detected. The chromatographic determination by HPLC-UV showed good selectivity, as can be observed in Figure 2.

Note that in Figure 2(a) it is shown a chromatogram of a real sample of water from the Monjolinho river which is characterized by the presence of domestic sewage. As can be attested by the chromatogram, the method is suitable for detecting and quantifying the herbicide at low concentrations, even at concentrations below the maximum allowed value for GLY in drinking water, which is $65 \mathrm{mg} \cdot \mathrm{L}^{-1}$ for Classes 1 and 2 natural waters [19].

The recovery varied from $84 \%$ to $95 \%$ for GLY. By Table 4 it also may be observed that the method adopted presents a good precision, as the coefficient of variation (CV) is less than $20 \%$ at all spiking levels.

Solutions prepared with the same stock solution diluted in water, at concentrations of 50,300 and $500 \mu \mathrm{g} \cdot \mathrm{L}^{-1}$ of glyphosate, were determined by HPLC-UV. Their areas under the curve (AUCs) were compared with the AUCs of the stock solution used for the recovery analysis.

The robustness of a method measures the sensitivity to small changes in experimental procedure [22]. Thus, tests were performed with the addition of methanol up to $20 \mathrm{~mL}$ to $1.0 \mathrm{~L}$ of the phosphate buffer solution. The $\mathrm{pH}$ was changed from 1.9 to 2.1 . The column temperature was modified progressively from $20^{\circ} \mathrm{C}$ to $30^{\circ} \mathrm{C}$ and the detection wavelength was fixed at $191 \mathrm{~nm}$ and then at $199 \mathrm{~nm}$. Measurements were performed on different days, by different analysts. Even with these changes, the results remained within acceptable limits of precision, accuracy and selectivity, proving the robustness of the method. The DOQ-CGCRE-008/2010 INMETRO, based on Brown and Forsythe [23], mentions that the greater the robustness greater the reliance of this method ant its accuracy. In addition to robustness, the repeatability was tested, which represents the consistency between the results of successive measurements by the same method, performed under the same conditions, with the same procedure, at the same location; repetitions were tested in a short period of time with satisfactory results.

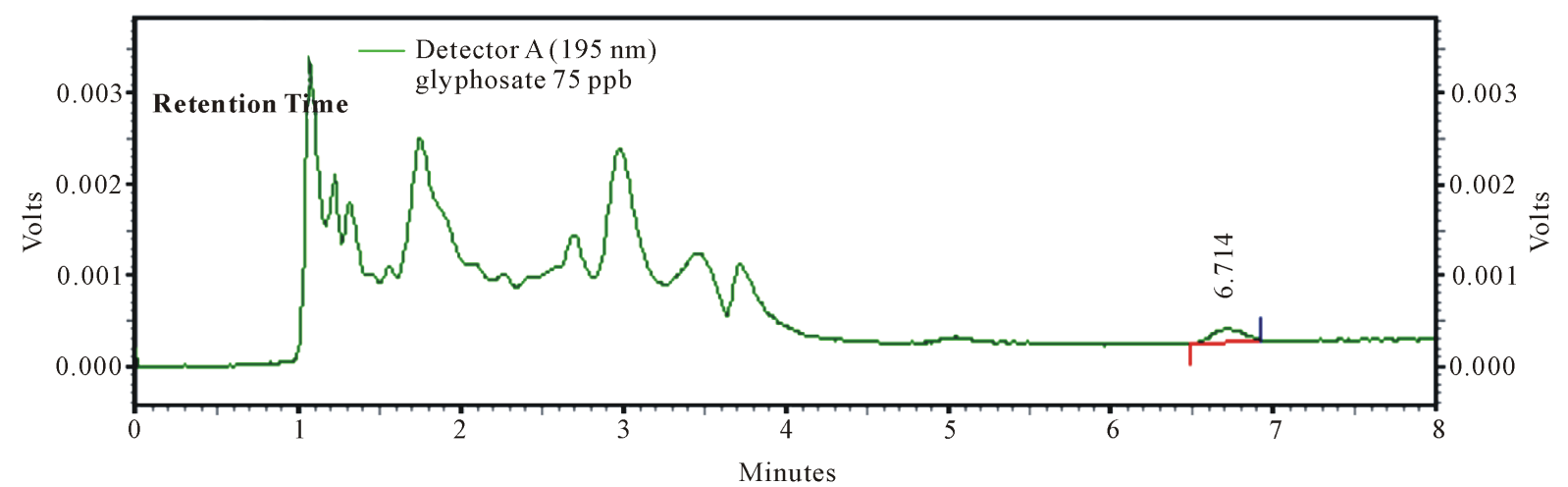

(a)

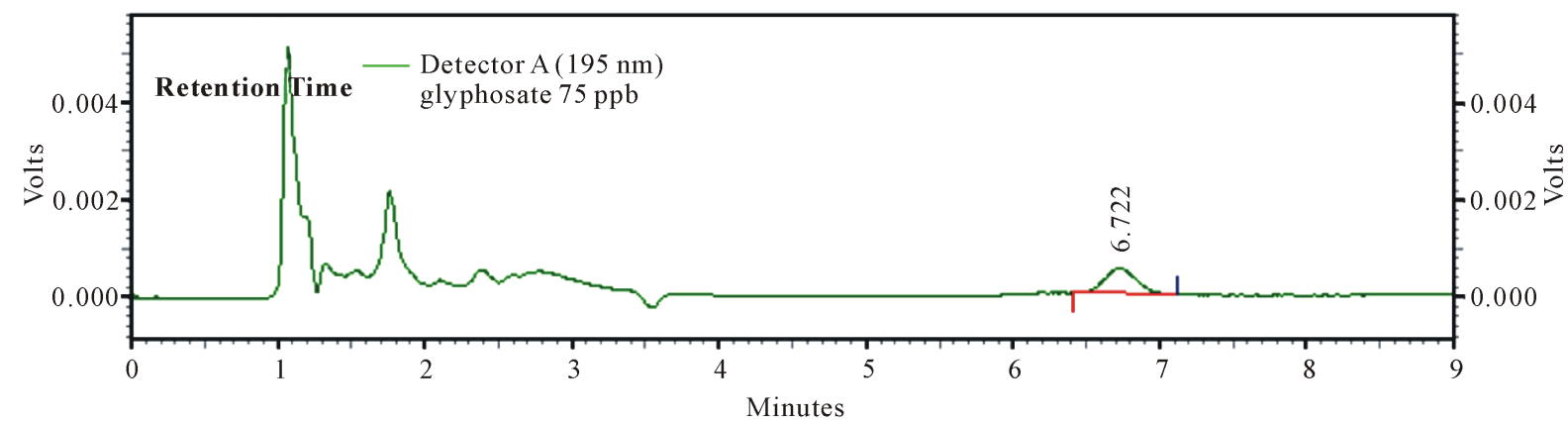

(b)

Figure 2. HPLC-UV chromatogram of a water sample of Monjolinho river, spiked with (a) $75 \mu \mathrm{g} \cdot \mathrm{L}^{-1}$ of GLY and (b) the standard solution $\left(75 \mu \mathrm{g} \cdot \mathrm{L}^{-1}\right)$. 


\subsubsection{Soil}

It is evident that the percent recovery of GLY is related to its soil adsorption. Thus, there is no rule for the increase or decrease of adsorption. Since it is a heterogeneous matrix, the soils may differ in the percentages of recovery. In this paper, the adsorption was not taken into account in the recovery determinations.

The recovery in five soil samples ranged from $86 \%$ to $114.8 \%$ for GLY. Furthermore, the HPLC-UV method showed good precision, with a coefficient of variation (CV) ranging between $2.43 \%$ and $18.6 \%$, at all spiking levels, according to Table 4.

One great advantage of HPLC-UV was the use of a buffer phosphate as mobile phase, which can be easily discarded, after a simple treatment, unlike most organic solvents that due to their toxicity can cause damage to human health and to the environment.

\subsection{Analysis of Glyphosate and AMPA by GC-MS}

For AMPA determination, the equation of the analytical curve was $y=26262.49 x-334480.20$, the coefficients $\mathrm{R}$ and $\mathrm{R}^{2}$ being 0.9901 and 0.9951 , respectively. The method limits of detection and quantitation for GC-MS were, respectively, $0.15 \mu \mathrm{g} \cdot \mathrm{L}^{-1}$ and $0.45 \mu \mathrm{g} \cdot \mathrm{L}^{-1}$ for water and 0.0006 and $0.0018 \mathrm{mg} \cdot \mathrm{kg}^{-1}$ for soil and sediment samples, respectively.

Figure 3 shows that the GC-MS method exhibited good selectivity for comparing the chromatogram of a standard solution (without matrix) to chromatograms of river water samples (Figure 3(a)—spiked at $500 \mu \mathrm{g} \cdot \mathrm{L}^{-1}$ ) and soil (Figure 3(b)—spiked at $50 \mathrm{mg} \cdot \mathrm{kg}^{-1}$ ). It can be noticed that the peaks of the interfering matrix did not elute with glyphosate and AMPA.

In Table 5 and Table 6 the results for the recovery of AMPA and glyphosate in water river samples and red latosol are presented. The values of recovery were acceptable, since they all ranged between $82.8 \%$ and $115 \%$ [24].

\begin{tabular}{ccc|}
\hline Table 4. Recovery efficiency for GLY in water, by HPLC-UV. \\
\hline Spiking Level $\left(\mu \mathrm{g} \cdot \mathrm{L}^{-1}\right)$ & Recovery (\%) & CV (\%) \\
\hline 50 & 86.0 & 18.6 \\
300 & 103.7 & 4.18 \\
500 & 114.8 & 2.43 \\
\hline
\end{tabular}

Table 5. Recovery (minimum and maximum) of glyphosate and AMPA respectively in water for $n=5$, by GC-MS.

\begin{tabular}{ccc}
\hline $\begin{array}{c}\text { Nominal Concentration } \\
\left(\mu \mathrm{g} \cdot \mathrm{L}^{-1}\right)\end{array}$ & Average Recovery $(\%)$ & CV\% \\
\hline 30 & $102 / 115$ & $18.5 / 14.1$ \\
90 & $105 / 106$ & $6.4 / 8.1$ \\
200 & $102 / 96.2$ & $7.7 / 7.1$ \\
\hline
\end{tabular}

Table 6. Recovery (minimum and maximum) of glyphosate and AMPA respectively in red latosol (A) and sandy soil (B) for $n=5$, by CG-MS.

\begin{tabular}{ccc}
\hline $\begin{array}{c}\text { Nominal Concentration } \\
\left(\mathrm{mg} \cdot \mathrm{kg}^{-1}\right)\end{array}$ & $\begin{array}{c}\text { Average Recovery } \\
(\%)\end{array}$ & CV\% \\
\multirow{2}{*}{6.0} & $70.1(\mathrm{~A}) / 89.8(\mathrm{~B})$ & $23.4(\mathrm{~A}) / 19.5(\mathrm{~B})$ \\
& $82.8(\mathrm{~A}) / 114(\mathrm{~B})$ & $18.9(\mathrm{~A}) / 20.2(\mathrm{~B})$ \\
& & \\
& $85.0(\mathrm{~A}) / 113(\mathrm{~B})$ & $6.2(\mathrm{~A}) / 14.1(\mathrm{~B})$ \\
& $98.7(\mathrm{~A}) / 92.4(\mathrm{~B})$ & $6.9(\mathrm{~A}) / 18.9(\mathrm{~B})$ \\
& $83.9(\mathrm{~A}) / 115(\mathrm{~B})$ & $13.0(\mathrm{~A}) / 19.0(\mathrm{~B})$ \\
& $82.1(\mathrm{~A}) / 106(\mathrm{~B})$ & \\
\hline
\end{tabular}




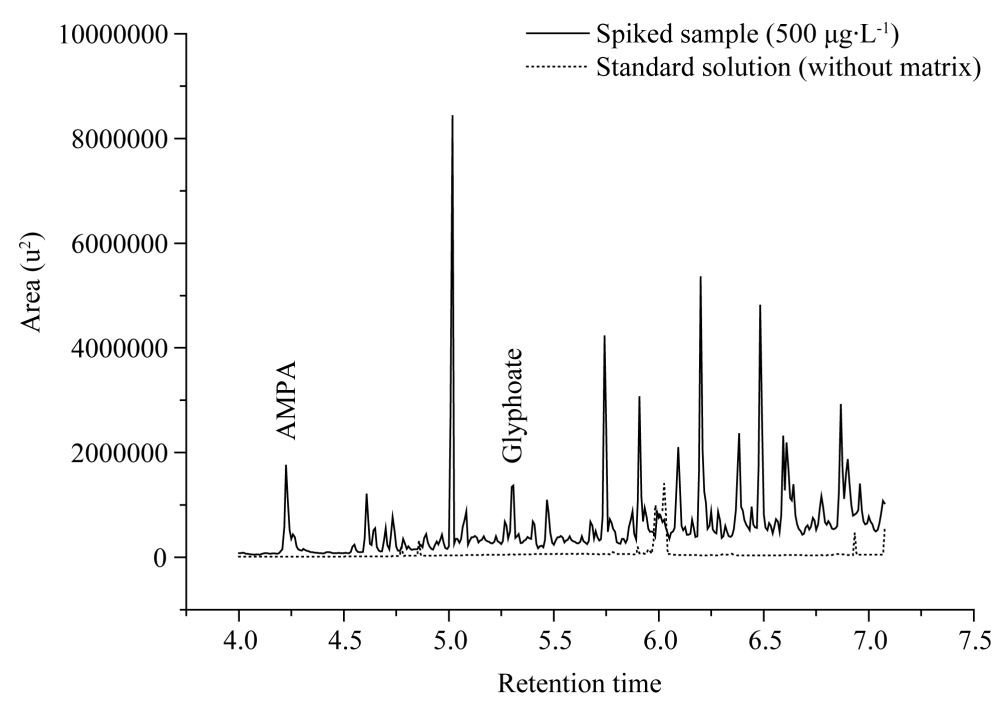

(a)

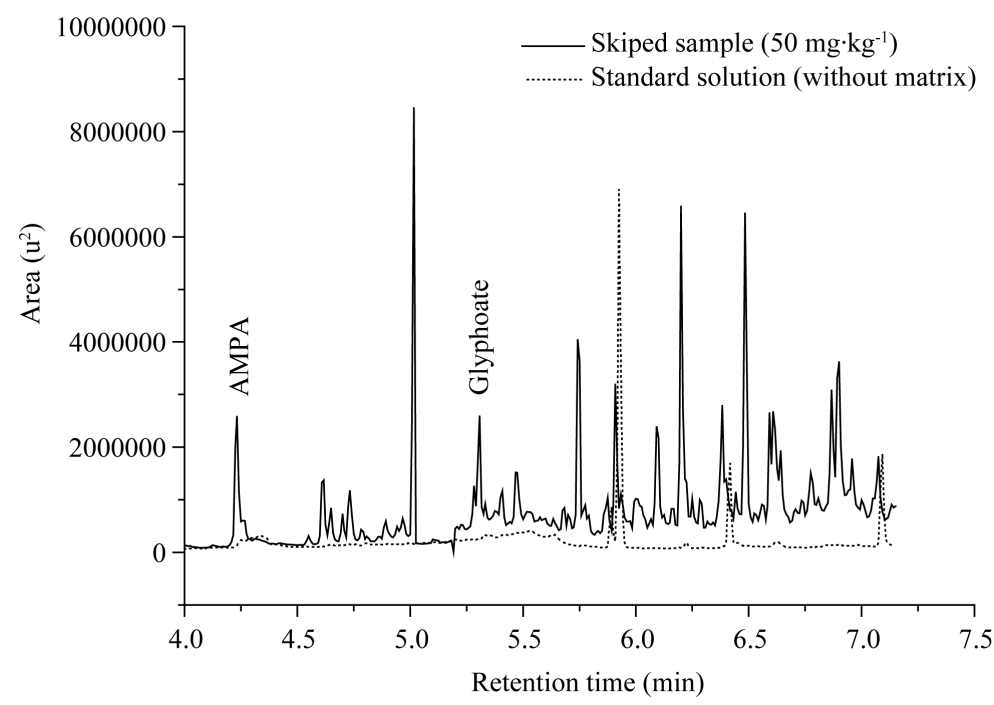

(b)

Figure 3. Superimposed GC-MS chromatograms of a water sample from the Monjolinho river (a) spiked at $500 \mu \mathrm{g} \cdot \mathrm{L}^{-1}$ and another standard solution $\left(500 \mu \mathrm{g} \cdot \mathrm{L}^{-1}\right)$ each of AMPA and glyphosate and soil sample (b) spiked at 50 $\mathrm{mg} \cdot \mathrm{kg}^{-1}$ and another standard solution $\left(500 \mu \mathrm{g} \cdot \mathrm{L}^{-1}\right)$ each of AMPA and glyphosate.

Robustness was assessed by the Youden test [22]. In this preliminary study, five factors that may affect the performance of the GC-MS method were varied: oven temperature, injector temperature, temperature of the interface, ion source temperature and linear velocity of carrier gas, as shown in Table 7.

It can be seen that the oven temperature influences the results, while, at lower temperatures, analytes can condense inside the column and decrease the retention time.

In the experiments, it was observed that oven temperature was the most important parameter influencing the robustness of the method, because at lower oven temperatures, the derivatized analytes may condense inside the column, resulting in higher retention time.

The linear velocity of the carrier gas and temperature of the ion source also had considerable influence on the analytical results, because the former is directly related to the residence time of the compound in the column and the latter is intrinsically linked to the fact that the ion source creates charged particles to bombard molecules, in 
order to obtain the molecular fragments to be analyzed by the detector. At a lower temperature, the smaller quantity of ions generated may impair the result of the analysis.

The injector temperature was shown to be the factor that least influences the analysis, but it should be noted that, in spite of minor relevance, it cannot be disregarded as, in the case of a cold injector, the compounds of interest could condense and invalidate the analytical results.

\subsection{HPLC x GC-MS}

As described in this paper, the glyphosate content can be determined by both HPLC-UV and GC-MS. It could be interesting to know which method provides the better analysis.

By GC-MS, the analysis proved to be linear, with a correlation coefficient (R) of 0.9963 and a coefficient of determination $\left(\mathrm{R}^{2}\right)$ of 0.9925 within the range of concentrations proposed. The equation for the analytical curve was $\mathrm{y}=23743.34 \mathrm{x}-78128.87$, where $\mathrm{y}$ is the area in the chromatogram obtained by glyphosate and $\mathrm{x}$ is the concentration corresponding to the area. LOD and LOQ were defined as in Ribani et al. [25], being respectively 0.67 and $2.02 \mu \mathrm{g} \cdot \mathrm{L}^{-1}$ for water samples and 0.0027 and $0.0081 \mathrm{mg} \cdot \mathrm{kg}^{-1}$ for soil and sediment samples, respectively. The determination by HPLC-UV also presented linearity, with $\mathrm{R}^{2}$ of 0.9966 in the concentration range from 50 to $500 \mu \mathrm{g} \cdot \mathrm{L}^{-1}$.

The equation of the calibration curve was $\mathrm{y}=25284.72 \mathrm{x}-187.68$, where $\mathrm{y}$ is the area in the chromatogram obtained by glyphosate and $\mathrm{x}$ is the concentration corresponding to the area, and LOD and LOQ were respectively, 9.93 and $30.1 \mathrm{\mu g} \cdot \mathrm{L}^{-1}$ for water samples and 0.040 and $0.120 \mathrm{mg} \cdot \mathrm{kg}^{-1}$ for soil and sediment samples. Table 8 summarizes the main analytical parameters.

The method proposed for HPLC-UV should be efficient with an anion exchange column, since the molecule of glyphosate has four ionizable groups that can protonate and dissociate, depending on the $\mathrm{pH}$ of the medium.

It is important to emphasize that the mobile phase in HPLC-UV system was an aqueous phosphate buffer, which has negligible negative effects on the environment. This factor must be taken into consideration, since it is avoided the use of organic solvents that, besides the cost of disposal, are generally toxic and cause negative environmental impacts.

Another favorable aspect of the HPLC-UV technique was the development of an analytical method for the determination of GLY in environmental soil and sediment samples without any clean-up step. Techniques used

Table 7. Chromatographic conditions varied in the GC-MS robustness test.

\begin{tabular}{ccc}
\hline Factor & Nominal & Variation \\
\hline Oven Temperature & $80(\mathrm{~A})$ & $70(\mathrm{a})$ \\
Injector Temperature & $280(\mathrm{~B})$ & $290(\mathrm{~b})$ \\
Interface Temperature & $260(\mathrm{C})$ & $270(\mathrm{c})$ \\
Ion Source Temperature & $200(\mathrm{D})$ & $190(\mathrm{~d})$ \\
Linear Velocity & $57.3(\mathrm{E})$ & $60.0(\mathrm{e})$ \\
\hline
\end{tabular}

Table 8. Analytical data for HPLC-UV versus GC-MS for determination of glyphosate.

\begin{tabular}{ccc}
\hline Parameters & HPLC-UV & GC-MS \\
\hline Working range & $50 \mathrm{a} 500 \mu \mathrm{g} \cdot \mathrm{L}^{-1}$ & $1 \mathrm{a} 500 \mu \mathrm{g} \cdot \mathrm{L}^{-1}$ \\
Limit of detection & $9.93 \mu \mathrm{g} \cdot \mathrm{L}^{-1}$ & $0.67 \mu \mathrm{g} \cdot \mathrm{L}^{-1}$ \\
Limit of quantitation & $30.1 \mu \mathrm{g} \cdot \mathrm{L}^{-1}$ & $2.02 \mu \mathrm{g} \cdot \mathrm{L}^{-1}$ \\
Line equation & $\mathrm{y}=25284.72 \mathrm{x}-187.68$ & $\mathrm{y}=23743.34 \mathrm{x}-78128.87$ \\
$\mathrm{R}$ & 0.9983 & 0.9963 \\
$\mathrm{R}^{2}$ & 0.9966 & 0.9925 \\
\hline
\end{tabular}


for clean-up, such as distillation, centrifugation and preparative column chromatography, which are generally tedious, requiring large volumes of organic solvents and exhibit poor repeatability/reproducibility, as a result of the several steps involved in the analysis.

HPLC-UV analysis thus offers several advantages, such as the absence of any specific derivatization reaction, which often causes extra demands in time and costs. Although the technique displays the benefits mentioned, the analysis of glyphosate by HPLC-UV has the drawback of being less sensitive than the GC-MS technique, and cannot determine AMPA.

\section{Conclusions}

Glyphosate (GLY) can lead to deleterious effects on the environment after prolonged use of excessive amounts. Therefore, there is a need to develop suitable methods for its determination and the determination of its primary degradation product: AMPA. In this context, the methods proposed here represent efficient ways of determining glyphosate and AMPA in water, soil and sediment.

The method developed with HPLC-UV is a sensitive and rapid technique to determine glyphosate. On the other hand, the method involving GC-MS is also sensitive and able to determine glyphosate and AMPA simultaneously, but requires more time of analysis.

It is concluded that both methods developed for the determination of GLY and AMPA meet current Brazilian legislation. However, the choice of method is left to the laboratory, in accordance with its needs.

Both methods offer LOD and LOQ within the acceptable maximum level permitted by law in treated water (65 $\mu \mathrm{g} \cdot \mathrm{L}^{-1}$ for glyphosate, and $500 \mu \mathrm{g} \cdot \mathrm{L}^{-1}$ for glyphosate plus AMPA).

\section{Acknowledgements}

The authors are very thankful for the support of the Secretariat of the Environment of the State of São Paulo and for the financial support of CNPq and CAPES. We also wish to thank the technician, Dr. Oscar dos Santos Neto, for providing particle size distributions.

\section{References}

[1] Corbera, M., Hidalgo, M., Salvadó, V. and Wieczorek, P.P. (2005) Determination of Glyphosate and Aminomethylphosphonic Acid in Natural Water Using the Capillary Electrophoresis Combined with Enrichment Step. Analytica Chimica Acta, 540, 3-7. http://dx.doi.org/10.1016/j.aca.2004.12.028

[2] Amarante Junior, O.P., Santos, T.C.R., Brito, N.M. and Ribeiro, M.L. (2002) Glifosato: Propriedades, Toxicidade, Usos e Legislação. Química Nova, 25, 420-428. http://dx.doi.org/10.1590/S0100-40422002000400014

[3] Assalin, M.R., De Moraes, S.G., Queiroz, S.C.N., Ferracini, V.L. and Duran. N.J. (2010) Studies on Degradation of Glyphosate by Several Oxidative Chemical Processes: Ozonation, Photolysis and Heterogeneous Photocatalysis. Journal of Environmental Science and Health, Part B, 45, 89-94. http://dx.doi.org/10.1080/03601230903404598

[4] Botta, F., Lavison, G., Couturier, G., Alliot, F., Moreau-Guigon, E., Fauchon, N., Guery, B., Chevreuil, M. and Blanchoud, H. (2009) Transfer of Glyphosate and Its Degradate AMPA to Surface Waters through Urban Sewerage Systems. Chemosphere, 77, 133-139. http://dx.doi.org/10.1016/j.chemosphere.2009.05.008

[5] Hsu, C.C. and Whang, C.W. (2009) Microscale Solid Phase Extraction of Glyphosate and Aminomethylphosphonic Acid in Water and Guava Fruit Extract Using Alumina-Coated Iron Oxide Nanoparticles Followed by Capillary Electrophoresis and Electrochemiluminescence Detection. Journal of Chromatography A, 1216, 8575-8580. http://dx.doi.org/10.1016/j.chroma.2009.10.023

[6] Souza, T.A., Matta, M.H.R., Montagner, E. and Abreu, A.B.G. (2006) Estudo de recuperação de glifosato e AMPA derivados em solo utilizando-se resinas nacionais. Química Nova, 29, 1372-1376. http://dx.doi.org/10.1590/S0100-40422006000600037

[7] Khrolenko, M.V. and Wieczorek, P.P. (2005) Determination of Glyphosate and Its Metabolite Aminomethylphosphonic Acid in Fruit Juices Using Supported-Liquid Membrane Preconcentration Method with High-Performance Liquid Chromatography and UV Detection after Derivatization with p-Toluenesulphonyl Chloride. Journal of Chromatography A, 1093, 111-117. http://dx.doi.org/10.1016/j.chroma.2005.07.062

[8] See, H.H., Hauser, P.C., Ibrahim, W.A.W. and Sanagi, M.M. (2010) Rapid and Direct Determination of Glyphosate, Glufosinate, and Aminophosphonic Acid by Online Preconcentration CE with Contactless Conductivity Detection. Electrophoresis, 31, 575-582. http://dx.doi.org/10.1002/elps.200900380

[9] Börjesson, E. and Torstensson, L. (2000) New Methods for Determination of Glyphosate and (Aminomethyl)phos- 
phonic Acid in Water and Soil. Journal of Chromatography A, 886, 207-216. http://dx.doi.org/10.1016/S0021-9673(00)00514-8

[10] Rodríguez, J.O.N.P. (2001) Exotic Species Introductions into South America: An Underestimated Threat? Biodiversity and Conservation, 10, 1983-1996. http://dx.doi.org/10.1023/A:1013151722557

[11] Dornelles, C.T.A. (2006) Percepção ambiental: Uma análise na bacia hidrográfica do Rio Monjolinho, São Carlos, SP. Doctorate Thesis, Universidade de São Paulo, São Paulo.

[12] CETESB (2001) Manual de Gerenciamento de Áreas Contaminadas. CETESB, São Paulo.

[13] http://www.laborsolo.com.br/arquivos/normativas/INM28.pdf.

[14] ABNT (1984) NBR 7181—Solo-Análise Granulométrica. Associação Brasileira de Normas Técnicas—ABNT, Rio de Janeiro.

[15] Sparks, D.L., Page, A.L., Helmke, P.A., Loeppert, R.H., Soltanpour, P.N., Tabatabai, M.A., Johnston, C.T. and Sumner, M.E. (1996) Methods of Soil Analysis_-Part 3: Chemical Methods. Soil Science Society of America, Madison.

[16] Alberguini, L.B.A., Silva, L.C. and Rezende, M.O.O. (2005) Tratamento de Resíduos Químicos: Guia Prático para a Solução dos Resíduos Químicos em Instituições de Ensino Superior. Rima, São Carlos.

[17] Olivares, I.R.B. and Lopes, F.A. (2012) Essential Steps to Providing Reliable Results Using the Analytical Quality Assurance Cycle. TrAC Trends in Analytical Chemistry, 35, 109-121. http://dx.doi.org/10.1016/j.trac.2012.01.004

[18] Barros Neto, B., Scarminio, I.S. and Bruns, R.E. (2007) Como Fazer Experimentos: Pesquisa e Desenvolvimento na Ciência e na Indústria. 3 Edition, Editora da Universidade de Campinas, Campinas.

[19] http://www.mma.gov.br/port/conama/res/res11/propresol_lanceflue_30e31mar11.pdf.

[20] Cantarella, H., van Raij B. and Quaggio, J.A. (1998) Soil and Plant Analyses for Lime and Fertilizer Recommendations in Brazil. Communications in Soil Science and Plant Analysis, 29, 1691-1706. http://dx.doi.org/10.1080/00103629809370060

[21] Araújo, R., Goedert, W.J. and Lacerda, M.P.C. (2007) Qualidade de um solo sob diferentes usos e sob cerrado nativo. Revista Brasileira de Ciência do Solo, 31, 1099-1108. http://dx.doi.org/10.1590/S0100-06832007000500025

[22] http://www.inmetro.gov.br/sidoq/arquivos/Cgcre/DOQ/DOQ-Cgcre-8_04.pdf.

[23] Brown, M.B. and Forsythe, A.B. (1974) Robust Tests for Equality of Variances. Journal of the American Statistical Association, 69, 364-367. http://dx.doi.org/10.1080/01621459.1974.10482955

[24] http://portal.anvisa.gov.br/wps/wcm/connect/4983b0004745975da005f43fbc4c6735/RE_899_2003_Determina+a+publ ica\%C3\%A7\%C3\%A3o+do+Guia+para+valida\%C3\%A7\%C3\%A3o+de+m\%C3\%A9todos+anal\%C3\%ADticos+e+bi oanal\%C3\%ADticos.pdf?MOD=AJPERES

[25] Ribani, M., Bottoli, C.B.G., Collins, C.H. and Jardim, I.C.S.F. (2004) Validação em métodos cromatográficos e eletroforéticos. Química Nova, 27, 771-780. http://dx.doi.org/10.1590/S0100-40422004000500017 